\title{
Functional Characterization of $\alpha 9$-Containing Cholinergic Nicotinic Receptors in the Rat Adrenal Medulla: Implication in Stress-Induced Functional Plasticity
}

\author{
Claude Colomer, ${ }^{1 \star}$ Luis A. Olivos-Oré, ${ }^{1,2 \star}$ Anne Vincent, ${ }^{1}$ J. Michael McIntosh, ${ }^{3}$ Antonio R. Artalejo, ${ }^{2}$ \\ and Nathalie C. Guérineau ${ }^{1}$ \\ ${ }^{1}$ Institute of Functional Genomics, Centre National de la Recherche Scientifique, Unité Mixte de Recherche 5203, Institut National de la Santé et de la \\ Recherche Médicale U661, University of Montpellier, 34094 Montpellier, France, ${ }^{2}$ Department of Toxicology and Pharmacology, Complutense University of \\ Madrid, 28040 Madrid, Spain, and ${ }^{3}$ Departments of Psychiatry and Biology, University of Utah, Salt Lake City, Utah 84112
}

An increase in circulating adrenal catecholamine levels constitutes one of the mechanisms whereby organisms cope with stress. Accordingly, stimulus-secretion coupling within the stressed adrenal medullary tissue undergoes persistent remodeling. In particular, cholinergic synaptic neurotransmission between splanchnic nerve terminals and chromaffin cells is upregulated in stressed rats. Since synaptic transmission is mainly supported by activation of postsynaptic neuronal acetylcholine nicotinic receptors (nAChRs), we focused our study on the role of $\alpha 9$-containing nAChRs, which have been recently described in chromaffin cells. Taking advantage of their specific blockade by the $\alpha$-conotoxin RgIA ( $\alpha$-RgIA), we unveil novel functional roles for these receptors in the stimulus-secretion coupling of the medulla. First, we show that in rat acute adrenal slices, $\alpha 9$-containing nAChRs codistribute with synaptophysin and significantly contribute to EPSCs. Second, we show that these receptors are involved in the tonic inhibitory control exerted by cholinergic activity on gap junctional coupling between chromaffin cells, as evidenced by an increased Lucifer yellow diffusion within the medulla in $\alpha$-RgIA-treated slices. Third, we unexpectedly found that $\alpha 9$-containing nAChRs dominantly $(>70 \%)$ contribute to acetylcholine-induced current in cold-stressed rats, whereas $\alpha 3$ nAChRs are the main contributing channels in unstressed animals. Consistently, expression levels of $\alpha 9$ $\mathrm{nAChR}$ transcript and protein are overexpressed in cold-stressed rats. As a functional relevance, we propose that upregulation of $\alpha 9$-containing $\mathrm{nAChR}$ channels and ensuing dominant contribution in cholinergic signaling may be one of the mechanisms whereby adrenal medullary tissue appropriately adapts to increased splanchnic nerve electrical discharges occurring in stressful situations.

\section{Introduction}

Catecholamines are one of the primary mediators for many of the physiological consequences of the organism's response to stressors. Once delivered into the blood circulation in response to stress, these mediators exert multiple actions enabling an organism to cope with a changing environment and to respond efficiently to a threat for its survival. Since chromaffin cells are the main source of circulating epinephrine, it is of interest to inves-

Received 0ct. 7, 2009; revised Feb. 25, 2010; accepted March 27, 2010.

This work was supported by grants from Centre National de la Recherche Scientifique (CNRS), Institut National de la Santé et de la Recherche Médicale, Ministère de I'Enseignement Supérieur et de la Recherche, Fondation pour la Recherche Médicale, Association pour la Recherche sur le Cancer Régionale, Région Languedoc-Roussillon, the Ministerio de Ciencia e Innovación (Grants BFU2005-06034 and CSD2008-00005), and the Comunidad de Madric (GrantS-SAL-0253-2006). We thank Drs. M.G. Desarménien and Norbert Chauvet for helpful discussion in preparing the manuscript and P. Didier, A. Carrette, E. Galibert, and D. Haddou for technical assistance. We also thank N. Lautredou at the microscope facility of Montpellier RIO Imaging-Centre Régional d'Imagerie Cellulaire plateform (IFR3).

${ }^{*}$ C.C. and L.A.0.0. contributed equally to this work.

Correspondence should be addressed to Nathalie C. Guérineau, Laboratoire de Biologie Neurovasculaire Intégrée, CNRS UMR6214; INSERM U771, University of Angers, UFR Sciences Médicales, 1 rue Haute de Reculée, 49045 Angers CEDEX 01, France. E-mail: nathalie.guerineau@univ-angers.fr.

C. Colomer's present address: Erasmus Medical Center, Department of Neuroscience, Dr. Molewaterplein 50, 3015 GE Rotterdam, The Netherlands.

DOI:10.1523/JNEUROSCI.4997-09.2010

Copyright $\odot 2010$ the authors $\quad 0270-6474 / 10 / 306732-11 \$ 15.00 / 0$ tigate how they ensure increased secretion upon stressful situations. Catecholamine secretion is regulated by both synaptic release of acetylcholine from splanchnic nerve terminals synapsing onto chromaffin cells (Douglas, 1968; Wakade, 1981) and local gap junction-mediated communication between chromaffin cells (Martin et al., 2001; Colomer et al., 2009). It is noteworthy that the cholinergic synaptic activity exerts a tonic inhibitory control on gap junctional coupling (Martin et al., 2003). Additionally, the two commands are upregulated in stressed rats (Colomer et al., 2008a). Although the mechanisms underlying upregulation of junctional coupling have been investigated (Colomer et al., 2008b), nothing is known regarding the increased neurotransmission.

At rat splanchnic nerve-chromaffin cell synapses, postsynaptic nicotinic receptors ( $\mathrm{nAChRs)} \mathrm{dominantly} \mathrm{contribute} \mathrm{to}$ acetylcholine-mediated excitatory responses and ensuing secretion (Douglas and Rubin, 1961; Wakade and Wakade, 1983). Although most nAChRs contain $\alpha$ and $\beta$ subunits, some contain only $\alpha$ subunits, as exemplified by $\alpha 7, \alpha 9$, and $\alpha 9 / \alpha 10 \mathrm{nAChRs}$. Multiple $\alpha$ and $\beta$ subunits have been identified in rat chromaffin cells (Di Angelantonio et al., 2003; Sala et al., 2008). Although the $\alpha 3$ subunit constitutes a major component of $\mathrm{nAChRs}$ activated in response to synaptically released acetylcholine (Criado et al., 
Table 1. Primer sequences used for quantitative PCR

\begin{tabular}{lll}
\hline & Forward sequence $\left(5^{\prime}-3^{\prime}\right)$ & Reverse sequence $\left(5^{\prime}-3^{\prime}\right)$ \\
\hline r $\alpha 3$ nAChR & TATAGAACTCCAACCACAC & CCGTAGAAGGTCCTCGTC \\
$r \alpha 7 n A C h R$ & AGCCATACCCAGATGTCACCTAC & GCAGCAAGAATACCAGCAGAGC \\
$r \alpha 9 n$ nAChR & AGCAAGAGCAGATTAGCAG & AAGCATACGCAACCTATCC \\
rGus & CACCACTGAGAGTAACAGGAAACAA & TCGTTGGCAATCCTCCAGTATCT \\
rHprt & TGACTATAATGAGCACTTCAGGGATT & TCGCTGATGACACAAACATGATT \\
rGAPDH & ATGATTCTACCCACGGCAAG & CTGGAAGATGGTGATGGGTT \\
\hline r, Rat. & &
\end{tabular}

A
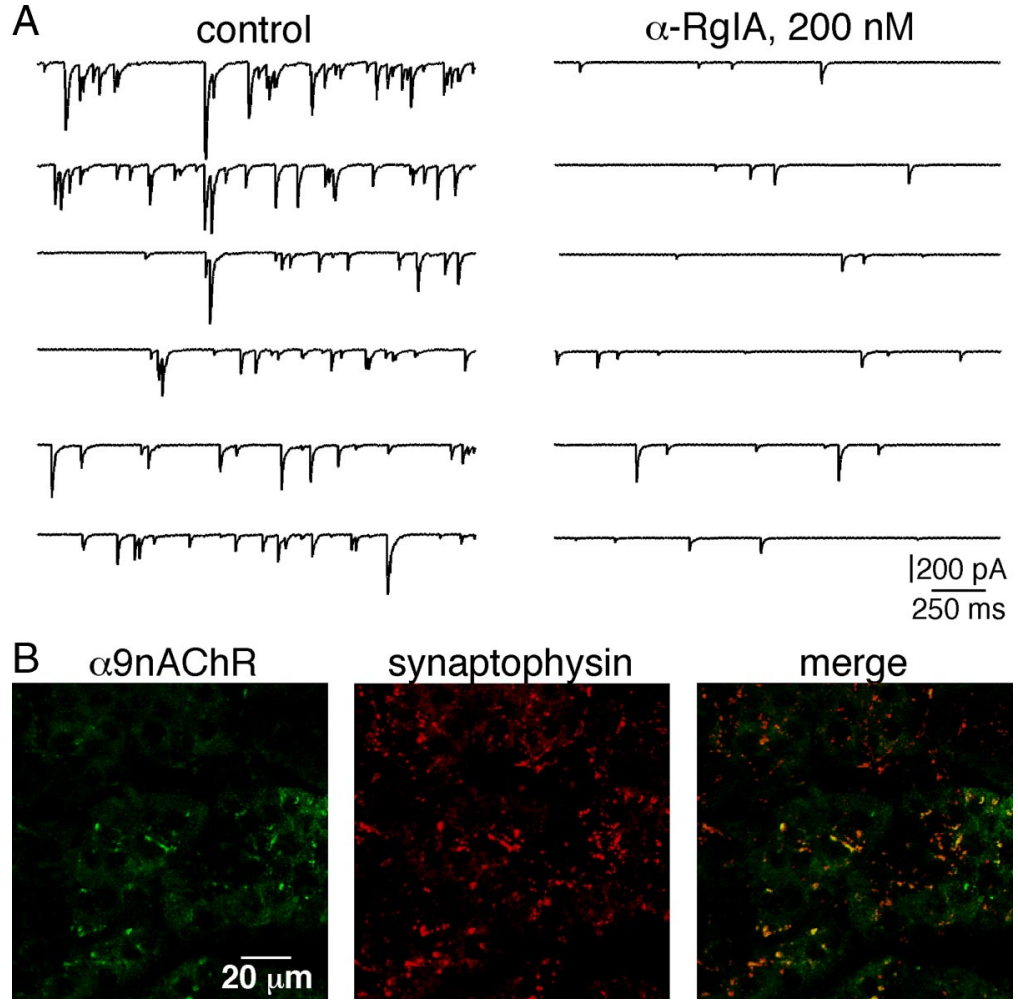

Figure 1. Involvement of $\alpha 9$-containing nAChRs in excitatory synaptic neurotransmission between splanchnic nerve endings and chromaffin cells. $A$, Representative chart recordings of spontaneous excitatory synaptic events recorded in a chromaffin cell voltage-clamped at $-80 \mathrm{mV}$, before (left panel) and $4 \mathrm{~min}$ after bath-applied $\alpha$-RglA (right panel). $\alpha$-RglA (200 nm) induces a decrease in both sEPSC frequency and amplitude. $\boldsymbol{B}$, Double immunostaining for $\alpha 9$ nAChRs and the presynaptic vesicle protein synaptophysin. As illustrated in the merge picture, labelings codistribute, indicative of a close localization between the two proteins.

1992; Nooney and Feltz, 1995; Barbara and Takeda, 1996), $\alpha 7$ built receptors are also involved in acetylcholine-mediated responses (López et al., 1998; Martin et al., 2003, 2005). The expression of $\alpha 9$ and $\alpha 10$ subunits in rat chromaffin cells (L. A. Olivos-Oré, L. Solís, C. Montiel, and A. R. Artalejo, unpublished observations) extends the tissular distribution of $\alpha 9 / \alpha 10$ nAChRs to a neuroendocrine tissue and raises the question of their role. $\alpha 9 / \alpha 10 \mathrm{nAChRs}$ display an unusual pharmacological profile as they can be activated by both nicotinic and muscarinic agonists (Verbitsky et al., 2000) and are highly permeable to $\mathrm{Ca}^{2+}$ (Katz et al., 2000). This prompted us to hypothesize that they may play unexpected roles in stimulussecretion coupling in the adrenal medulla. In particular, whether they contribute to synaptic neurotransmission and whether they are modulated upon increased synaptic activity remains unknown.

To address the functional role of $\alpha 9$-containing nAChRs in the adrenomedullary tissue, we took advantage of its potent and selective blockade by the $\alpha$-conotoxin RgIA ( $\alpha$-RgIA) (Ellison et al., 2006; Vincler et al., 2006; Olivera et al., 2008; Pérez et al., 2009). Our results obtained in rat acute adrenal slices show that $\alpha 9$-containing nAChRs are involved in the excitatory neurotransmission at the splanchnic nerve-chromaffin cell synapse and in the tonic inhibitory control exerted by cholinergic activity on gap junctional coupling. In addi, $\alpha 9$ subunit expression level is upregulated in cold-stressed rats, making $\alpha 9$-containing $\mathrm{nAChR}$ a major determinant in acetylcholine-induced current.

\section{Materials and Methods}

All procedures in this study conformed to the animal welfare guidelines of the European Community and were approved by the French Ministry of Agriculture (authorization no. 34.247).

Adrenal slice preparation. Acute slices were prepared from 8- to 12-week-old Wistar male rats (Janvier) as reported previously (Martin et al., 2001). After removal, the glands were kept in ice-cold saline for $2 \mathrm{~min}$. A gland was next glued onto an agarose cube and transferred to the stage of a vibratome (DTK-1000, D.S.K; Dosaka). Slices of $200 \mu \mathrm{m}$ thickness were cut with a razor blade and transferred to a storage chamber maintained at $37^{\circ} \mathrm{C}$ and containing Ringer's saline, which contained the following (in $\mathrm{mM}$ ): $125 \mathrm{NaCl}, 2.5 \mathrm{KCl}, 2$ $\mathrm{CaCl}_{2}, 1 \mathrm{MgCl}_{2}, 1.25 \mathrm{NaH}_{2} \mathrm{PO}_{4}, 26 \mathrm{NaHCO}_{3}$, 12 glucose and buffered to $\mathrm{pH}$ 7.4. The saline was continuously bubbled with carbogen $\left(95 \% \mathrm{O}_{2} / 5 \% \mathrm{CO}_{2}\right)$.

Stress paradigm. In some experiments, rats were subjected to a cold stress paradigm (Colomer et al., 2008a,b). Upon entrance to the colony, rats were allowed to acclimatise to the animal facility for a minimum of $7 \mathrm{~d}$ before use. They were housed initially three per cage and then singly housed for the duration of the experiments. Rats were randomly assigned to a cold-exposed or control group. Cold-stressed rats were kept in clear plastic cages with bedding and continuously exposed to an ambient temperature of $4^{\circ} \mathrm{C}$ for $5 \mathrm{~d}$ in a temperaturecontrolled cold chamber. Control rats were housed in similar conditions but at $22^{\circ} \mathrm{C}$. For each series of experiments, and to avoid an additional stress due to isolation, we made sure that at least two rats underwent the same protocol (control or cold exposure) at the same time. The rooms were maintained on a $12 \mathrm{~h}$ light/dark cycle (light on from 8 A.M. to 8 P.M.). Food and water were available ad libitum.

Electrophysiology. All experiments were performed in the whole-cell configuration of the patch-clamp technique (Hamill et al., 1981). Patch pipettes were pulled to a resistance of $5-8 \mathrm{M} \Omega$ from borosilicate glass and filled with the following internal solution (in $\mathrm{mm}$ ): 140 potassiumgluconate, $2 \mathrm{MgCl}_{2}, 1.1 \mathrm{EGTA}$, and 5 HEPES, which was titrated to $\mathrm{pH}$ 7.2 with $\mathrm{KOH}$. Adrenal slices were transferred to a recording chamber attached to the stage of an upright microscope (Axioskop FS, Zeiss) and continuously superfused with Ringer's saline at $34^{\circ} \mathrm{C}$. Spontaneous EPSCs (sEPSCs) were recorded in chromaffin cells voltage clamped at $-80 \mathrm{mV}$ using an EPC-9 patch-clamp amplifier (HEKA Electronik) and were filtered at $1 \mathrm{kHz}$. Signals were acquired and analyzed using Pulse and PulseFit software (version 8.50; HEKA Electronik). In some cells, a quantal analysis of sEPSCs was performed. Note that sEPSCs are independent of presynaptic action potentials at the splanchnic nerve-chromaffin cell synapse (Barbara and Takeda, 1996; Kajiwara et al., 1997). sEPSCs were analyzed by using Clampfit 9.0 (Molecular Devices). Only single events were selected for construction of amplitude histograms. 
These histograms were then inspected for the presence of peaks and a corresponding number of Gaussians was then fitted by nonlinear regression using Igor Pro 5.04.8 (Wavemetrics). Quantal size was estimated from the mean value of the first Gaussian curve fitted to the amplitude distribution histogram.

Dye transfer assay. The fluorescent dye LY (Lucifer yellow-CH, lithium salt, $0.5 \mathrm{~mm}$ in the above-mentioned internal solution) was introduced into chromaffin cells using patch pipettes. Cells were viewed with a $63 \times$ 0.9 numerical aperture Achroplan water-immersion objective (Zeiss). Dye transfer between gap junction-coupled cells was visualized with a real-time confocal laser-scanning microscope equipped with an $\mathrm{Ar} / \mathrm{Kr}$ laser (Odyssey XL with InterVision 1.5.1 software; Noran Instruments). LY diffusion was imaged using the $488 \mathrm{~nm}$ centered wavelength of the laser beam. The largest detection slit $(100 \mu \mathrm{m})$ of the confocal microscope was used, giving images with a $3.1 \mu \mathrm{m}$ axial resolution. The extent of LY diffusion was estimated by counting the number of neighboring cells that received dye within $30 \mathrm{~min}$. The probability of LY diffusion was expressed as a ratio corresponding to the number of injected cells that showed dye transfer to adjacent cells over the total number of injected cells.

Immunostaining. To process for immunolabeling, the adrenal glands from control and cold-stressed rats were removed and fixed by immersion in $4 \%$ paraformaldehyde in $0.1 \mathrm{~m}$ phosphate buffer [ $4 \mathrm{~h}$ at room temperature (RT)]. They were then cut using a vibratome (Leica VT1000S; Leica Microsystems) into $50 \mu \mathrm{m}$ thick sections. Sections were incubated for $48 \mathrm{~h}$ at $4^{\circ} \mathrm{C}$ with a goat polyclonal antibody raised against $\alpha 9$ nAChR (1:250; Santa Cruz Biotechnology) and a mouse monoclonal antibody against the presynaptic protein synaptophysin (1:1000, clone SVP-38; Sigma). Sections were then incubated (3 h at RT) with appropriate secondary antibodies conjugated to Alexa 488 (1:2000; Invitrogen) or Cy3 (1:2000; Jackson ImmunoResearch Laboratories). Primary and secondary antibodies were diluted in PBS containing 2\% BSA and $0.1 \%$ Triton X100. Stained sections were imaged with a Biorad MRC 1024 confocal laser scanning microscope equipped with a krypton-argon mixed gas laser emitting at 488 and $568 \mathrm{~nm}$. The specificity of the commercial antibodies has been assessed by absorption tests. Negative controls were performed by omitting primary antibodies. Quantitative analysis of colocalization between synaptophysin and $\alpha 9 \mathrm{nAChR}$ was performed using ImageJ software, as previously described (Chauvet et al., 2003). Briefly, a fixed threshold for the fluorescent intensity was set to remove background and include only labeled puncta. The thresholded images were then converted to binary images, pseudocolored, and the lookup table was inverted so that binary images showed a green labeling for $\alpha 9 \mathrm{nAChRs}$ and a red labeling for synaptophysin-positive presynaptic terminals. After superimposition of binary images, synaptophysin puncta codistributed with $\alpha 9 \mathrm{nAChRs}$ were counted and results were expressed as a percentage of colocalization of synaptophysin staining over $\alpha 9$ nAChR staining.

Western blotting. After decapsulation of the adrenal gland, medullary tissue was separated from the cortex. To remove remaining cortical cells, samples were incubated for $10 \mathrm{~min}$ at $0-4^{\circ} \mathrm{C}$ in Ringer's saline containing $1 \mathrm{mg} / \mathrm{ml}$ collagenase type I. Membrane proteins were then isolated using lysis buffer (10 mм Tris- $\mathrm{HCl}, \mathrm{pH}$ 7.4, 5 mм EDTA, 1 mм sodium orthovanadate, and $10 \mathrm{~mm} \mathrm{NaF}$ as phosphatase inhibitors, and $10 \mathrm{~mm}$ $\beta$-glycerophosphate and $1 \%$ Triton X-100), supplemented with Mini complete protease inhibitors (Roche Applied Science). Proteins were centrifuged once for $5 \mathrm{~min}$ at $5000 \mathrm{rpm}$ and supernatants were collected. Proteins were centrifuged for $30 \mathrm{~min}$ at 13,200 rpm and concentrations were determined using the DC protein assay kit (Bio-Rad Laboratories). Protein samples $(40 \mu \mathrm{g})$ were heated for $5 \mathrm{~min}$ at $95^{\circ} \mathrm{C}$ and separated on a $10 \%$ polyacrylamide gel in parallel with molecular weight markers. Electrophoresed proteins were transferred onto a nitrocellulose membrane ( $80 \mathrm{~V}, 75 \mathrm{~min}$ ) using a semidry blotting system (Bio-Rad Laboratories). Blots were then blocked with $10 \%$ blocking reagent (BM chemoluminescence blotting substrate kit; Roche Applied Science) in TBS ( $\mathrm{pH} 7.4,0.1 \%$ Tween 20 ) for $1 \mathrm{~h}$ at room temperature with gentle agitation. Blots were then incubated with the same $\alpha 9 \mathrm{nAChR}$ polyclonal antibody as that used for immunofluorescence in TBS-Tween $0.1 \%$ containing $10 \%$ blocking reagent at $4^{\circ} \mathrm{C}$ overnight. Following washout, blots were incubated with a peroxidase-conjugated secondary antibody for $1 \mathrm{~h}$ at room temperature. This was followed by 1 min incubation in BM chemoluminescence blotting substrate. Labeled blots were then exposed to Fujifilm medical $x$-ray film to visualize antibody binding. To ensure equal loading of protein samples, blots were stripped of the $\alpha 9 \mathrm{nAChR}$ antibody and reprobed with an actin-specific monoclonal antibody (actin, pan Ab-5, clone ACTN05, 1:1000; Interchim). Intensities of $\alpha 9$ $\mathrm{nAChR}$ bands were normalized to those of actin and quantified using ImageJ software.

Quantification of mRNA expression levels by real-time PCR. Total RNA was extracted from macrodissected adrenal medulla and treated with DNase I using the RNeasy micro extraction kit (Qiagen). RNA ( $1 \mu \mathrm{g})$ was first reverse transcribed using Superscript III reverse transcriptase (Invitrogen) and $250 \mathrm{ng}$ of random hexamer (GE Healthcare) in a final volume of $20 \mu \mathrm{l}$. Real-time PCR analyses of $\alpha 3 \mathrm{nAChR}, \alpha 7 \mathrm{nAChR}$, $\alpha 9 \mathrm{nAChR}$, and housekeeping genes were performed using SYBR Green PCR master mix (Applied Biosystems) with 1:10 of the reversetranscription reaction, and were performed on an ABI 7500 sequence detector (Applied Biosystems). Primer sequences for rat $\alpha 3 \mathrm{nAChR}$, rat $\alpha 7 \mathrm{nAChR}$, rat $\alpha 9 \mathrm{nAChR}$, and housekeeping genes are given in Table 1 . The concentration of the primers used was $300 \mathrm{~nm}$ for $\alpha 3 \mathrm{nAChR}$, $\alpha 7 \mathrm{nAChR}, \alpha 9 \mathrm{nAChR}$, and housekeeping genes. After an initial denaturation step for $10 \mathrm{~min}$ at $95^{\circ} \mathrm{C}$, the thermal cycling conditions were 40 cycles at $95^{\circ} \mathrm{C}$ for $15 \mathrm{~s}$ and $60^{\circ} \mathrm{C}$ for $1 \mathrm{~min}$. Each sample value was determined from triplicate measurements. The selection of appropriate housekeeping genes was performed with geNorm (Vandesompele et al., 2002). Expression of $\alpha 3, \alpha 7$, and $\alpha 9$ nAChR transcripts was normalized to the geometric mean of the expression levels of three housekeeping genes, Hprt (hypoxanthine-guanine phosphoribosyltransferase), GAPDH (glyceraldehyde-3-phosphate dehydrogenase), and Gus (Glucuronidase), according to the formula $\mathrm{Cx} /$ geometric mean $(\mathrm{R} 1, \mathrm{R} 2, \mathrm{R} 3)=$ $2^{-(\mathrm{Ct}[\mathrm{Cx}]-\text { arithmetic mean }[\mathrm{Ct}(\mathrm{R} 1), \mathrm{Ct}(\mathrm{R} 2), \mathrm{Ct}(\mathrm{R} 3)])}$, where $\mathrm{Ct}$ is the threshold cycle and R1, R2, and $\mathrm{R} 3$ are the three reference genes.

Solutions and chemicals. The $\alpha 3$-built nicotinic receptor blocker hexamethonium (hexamethonium chloride), LY, collagenase type I, acetylcholine chloride, and the gap junction blocker carbenoxolone were purchased from Sigma. Primers for quantitative PCR were purchased from MWG-Biotech. The $\alpha$-RgIA conotoxin was synthesized by previously described methods (Cartier et al., 1996). To investigate the blocking effect of hexamethonium and $\alpha$-RgIA on acetylcholine (ACh)-evoked inward current, the pharmacological blockers were continuously pressure-ejected (during 4 min before ACh stimulation) from an extracellular micropipette (tip diameter $2-5 \mu \mathrm{m}$ ) that was positioned in the vicinity of the recorded chromaffin cell. Cells were briefly stimulated ( $1 \mathrm{~s}$ ) by the cholinergic agonist ACh that was also pressure-applied. To examine the effect of $\alpha$-RgIA on sEPSCs, the toxin was pressure-applied for $4 \mathrm{~min}$ in the vicinity of the voltage-clamped cell before the recording of synaptic currents.

Statistics. Numerical data are expressed as the mean \pm SEM. Differences between groups were assessed by using the nonparametric MannWhitney $U$ test. Unpaired or paired Student's $t$ test was used to compare means when appropriate. Percentages were compared using a contingency table and the $\chi^{2}$ test. Differences with $p<0.05$ were considered significant.

\section{Results}

In the absence of specific cholinergic agonists acting at $\alpha 9$ subunit-built nAChR channels, the functional role of these nicotinic receptors in the rat adrenal medulla was assessed by using a recently discovered toxin isolated from the Western Atlantic species Conus regius, $\alpha$-RgIA. $\alpha$-RgIA specifically and potently antagonizes $\alpha 9$ - and $\alpha 9 / \alpha 10$-built nAChRs (Ellison et al., 2006, 2008). In all experiments, we used the toxin at a concentration that is effective to block rat $\alpha 9$-containing nAChR channels and without any effect on the closely related $\alpha 7$-built nAChRs (Ellison et al., 2006; Vincler et al., 2006). 
A

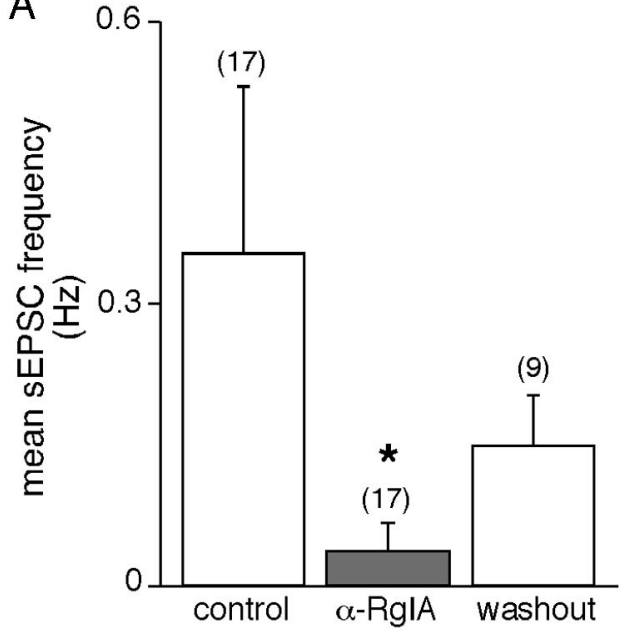

B

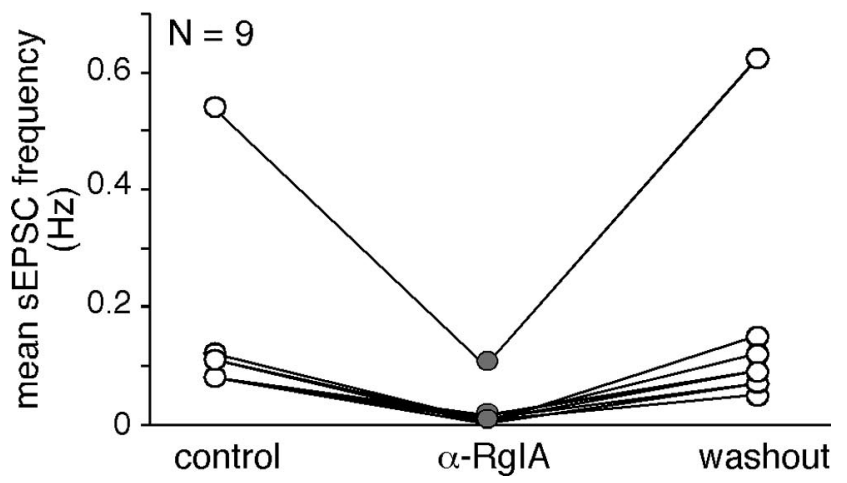

Figure 2. Effect of $\alpha 9$-containing nAChR blockade on sEPSC frequency. $\boldsymbol{A}$, Histogram illustrating the blocking effect of the toxin $\alpha$-RglA on the mean sEPSC frequency calculated in 17 cells. ${ }^{*} p<0.05$ (paired $t$ test), compared with control frequency calculated before toxin application. $B$, Distribution of mean sEPSC frequency in the nine cells in which synaptic events were recorded before, during, and after $\alpha$-RglA application. Note that the effect of the toxin is reversible.

\section{$\alpha 9$-containing nAChRs are involved in synaptic neurotransmission between splanchnic nerve terminals and chromaffin cells}

To determine whether $\alpha 9$-containing nAChRs contribute to cholinergic synaptic transmission at the splanchnic nervechromaffin cell junction, sEPSCs were recorded in whole-cell voltage-clamped chromaffin cells in the absence or in the presence of the $\alpha$-RgIA conotoxin (Fig. 1A). The effect of $\alpha$-RgIA on synaptic events was examined after a 4 min continuous application of the toxin. $\alpha$-RgIA (200 nM) led to a decreased synaptic activity when compared with control condition. This result strongly suggests that $\alpha 9$-containing $\mathrm{nAChRs}$ are activated in response to in situ synaptically released ACh. To determine whether $\alpha 9$ nAChRs have a synaptic distribution, their colocalization with the $38 \mathrm{kDa}$ presynaptic vesicle protein synaptophysin (Wiedenmann and Franke, 1985) was assessed using double immunostaining. As illustrated in Figure $1 B$, labeling of $\alpha 9$ nAChRs matches closely that of synaptophysin, supporting the hypothesis of a synaptic/perisynaptic localization. Altogether, these results consistently fit with an activation of $\alpha 9$-containing $\mathrm{nAChR}$ channels upon ACh release in the synaptic cleft and represent the first documentation of a functional role of $\alpha 9$ containing nAChRs in the adrenal medullary tissue. This finding also extends available data on the expression of nAChR subtypes
A

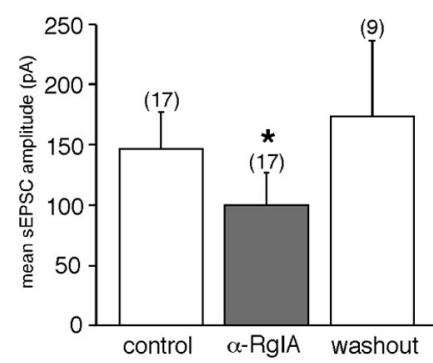

B

C

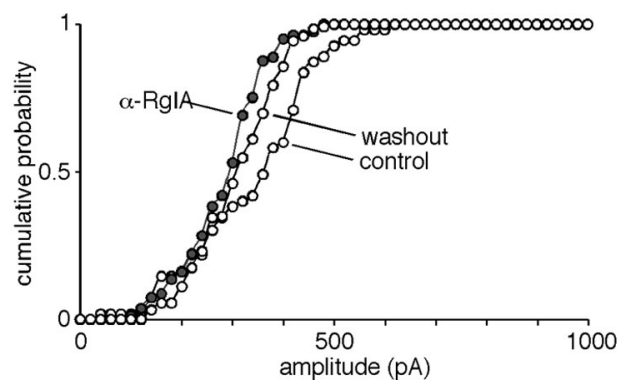

Figure 3. Effect of $\alpha 9$-containing $n A C h R$ blockade on sEPSC amplitude. $A$, Histogram illustrating the blocking effect of the toxin $\alpha$-RgIA on the mean sEPSC amplitude. A 4-10 min washout is sufficient for a complete recovery. ${ }^{*} p<0.05$ (paired $t$ test), compared with control SEPSC amplitude calculated before toxin application. $\boldsymbol{B}$, Illustration of the $5 E P S C$ amplitude variance distribution for each recorded cell. Lines represent the four cells in which the number of SEPSCs recorded before, during, and after toxin application was large enough to calculate the amplitude variance (from 10 to 150 synaptic events). $\alpha$-RgIA reduced the amplitude variance value. C, Distribution of the cumulative probability plotted from sEPSC amplitudes recorded in one representative cell. Note that the two-modal distribution observed under control condition disappeared in the presence of $\alpha$ - $\mathrm{RgIA}$, indicating a preferential action of the toxin on high amplitude synaptic events.

at the cholinergic synapse between splanchnic nerve endings and chromaffin cells and their activation in response to synaptically release ACh.

As seen in Figure 1, both sEPSC frequency and amplitude were affected by the toxin $\alpha$-RgIA. A more detailed analysis is presented in Figures 2, 3, and 4. In the presence of $\alpha$-RgIA, sEPSC frequency was significantly decreased $(0.36 \pm 0.17 \mathrm{~Hz}, n=17$ in control conditions vs $0.04 \pm 0.03 \mathrm{~Hz}, n=17$ in the presence of $\alpha$-RgIA, $p<0.05$ ) (Fig. $2 A$ ). On average, $\alpha$-RgIA reduced sEPSC frequency by $62 \pm 8 \%(n=17)$. $\alpha$-RgIA-induced decrease in sEPSC frequency was reversible after 5 min washout (in 9 of the 9 cells tested for reversibility, $p<0.05$ ) (Fig. $2 B$ ). Not only sEPSC frequency was affected by $\alpha$-RgIA, but also sEPSC amplitude, although to a lesser extent (Fig. 3). In the presence of $\alpha$-RgIA, sEPSC amplitude was significantly decreased $(147 \pm 29 \mathrm{pA}, n=$ 17 in control conditions vs $100 \pm 26 \mathrm{pA}, n=17$ in the presence of $\alpha$-RgIA, $p<0.05$ ) (Fig. 3A). On average, $\alpha$-RgIA reduced sEPSC amplitude by $\sim 36 \%(n=17)$. As illustrated by the plot of sEPSC amplitude variance (Fig. $3 B$ ), $\alpha$-RgIA reduced the amplitude variance value, supporting the finding that the toxin acts by homogenizing sEPSC amplitudes. Accordingly, the distribution of cumulative probability plotted from sEPSC amplitude recorded in one representative cell exhibited a bimodal distribution including both low and high amplitude ( $>400 \mathrm{pA})$ events in control condition, and a decreased proportion of these high amplitude events in the presence of $\alpha$-RgIA (Fig. 3C). To go further, we next performed a quantal analysis of sEPSCs (Fig. 4). In control saline, the mean quantal size of sEPSCs was $20 \pm 2.4$ 

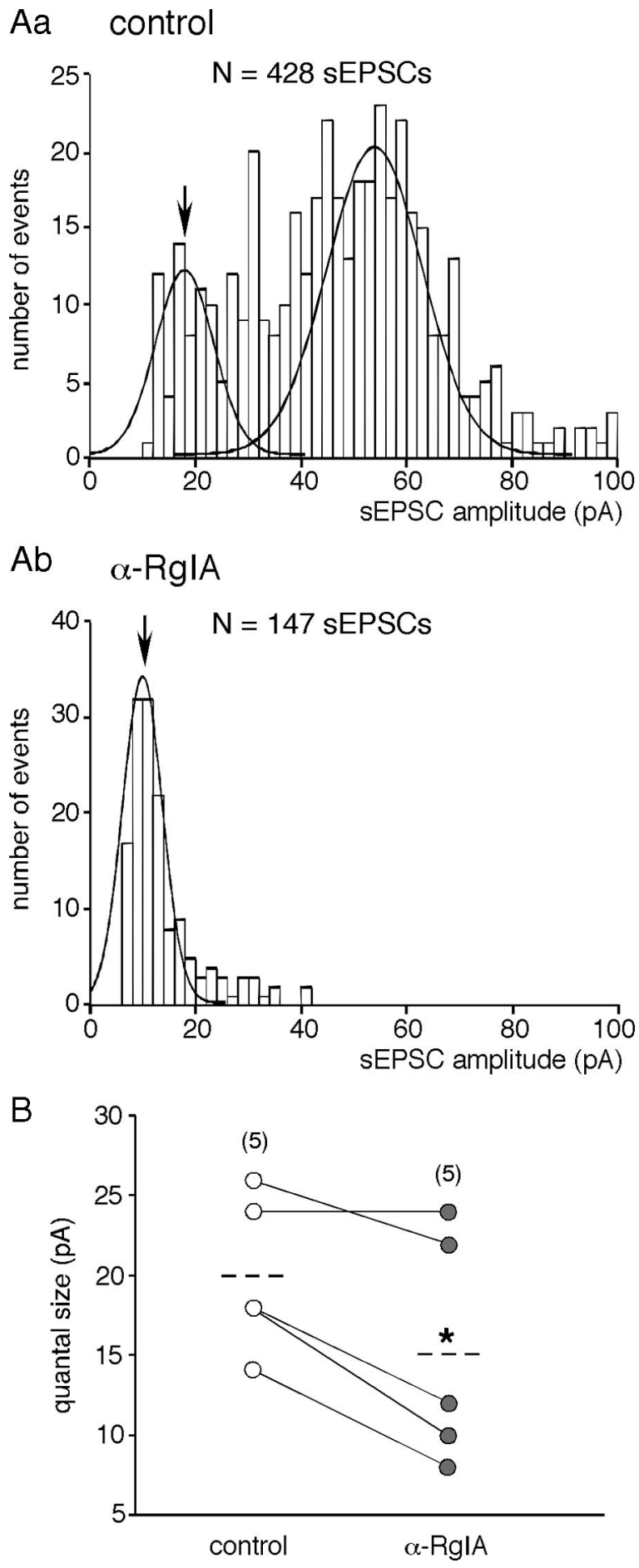

Figure 4. Effect of $\alpha 9$-containing nAChR blockade on sEPSC quantal size. $\boldsymbol{A} \boldsymbol{a}, \boldsymbol{A} \boldsymbol{b}$, Representative histograms (bin size of $2 \mathrm{pA}$ ) of the distribution of sEPSC amplitudes in a chromaffin cell, recorded in control ( $\boldsymbol{a}$ ) and in $\alpha$-RglA-containing saline $(\boldsymbol{b})$. Quantal size was estimated from the mean value of the first Gaussian fitted to the amplitude histogram. $\alpha$-RglA induced both a switch from a bimodal to a unimodal amplitude distribution and a decrease in SEPSC quantal size (arrows). $\boldsymbol{B}$, Pooled data from the five cells in which the quantal analysis was performed. As symbolized by the dashed lines, toxin application decreased the mean quantal size by $\sim 27 \%$ $\left({ }^{*} p<0.05\right.$, paired $t$ test).

pA $(n=5)$. This value does not differ from those previously reported (Barbara and Takeda, 1996; Kajiwara et al., 1997). As shown in Figure $4 A b, \alpha$-RgIA diminished the relative contribution of larger events to amplitude histograms, leading to a switch from a bimodal to an unimodal amplitude distribution. This effect is consistent with a decrease of release probability at splanchnic nerve terminals. Additionally, in $\alpha$-RgIA-containing saline, the quantal size was reduced (Fig. $4 A$ ), as evidenced by a leftward shift of the first Gaussian peak. This is consistent with an action on postsynaptic $\alpha 9$-containing nAChRs receptors. This effect was observed in 4 of 5 recorded cells (mean decrease of $34 \pm 6.7 \% ; n=4$ ) (Fig. $4 B$ ). We noticed that the effect of $\alpha$-RgIA on sEPSC quantal size and sEPSC frequency differed from one cell to another. In the majority of cells, $\alpha$-RgIA reduced both the quantal size and the frequency, whereas in others it reduced either one or the other. This suggests that the toxin may affect the frequency and the quantal size independently, implying separate modulatory effects of presynaptic and postsynaptic $\alpha 9$-containing nAChRs.

\section{$\alpha 9$-containing nAChRs tonically inhibit gap junction-mediated cell-to-cell communication}

As previously reported (Martin et al., 2003), nAChRs exert a tonic inhibitory control on gap junctional communication between chromaffin cells. To investigate the ability of $\alpha 9$-containing nAChRs to modulate gap junctional coupling, we imaged Lucifer yellow diffusion by real-time confocal microscopy during $30 \mathrm{~min}$ with an image acquisition every $5 \mathrm{~min}$ (Fig. 5). A $30 \mathrm{~min}$ bath application of $\alpha$-RgIA significantly increased the probability of LY diffusion from the patched cells to 1-2 adjacent cells $(p<$ 0.05 for time $\geq 15 \mathrm{~min}$ ). By contrast, in control slices, the number of fluorescent cells did not change during the recording time and was preferentially restricted to the patched cells, as recently reported (Colomer et al., 2008b). As expected for a gap junction-mediated effect, $\alpha$-RgIA did not affect LY diffusion when applied after $15 \mathrm{~min}$ incubation in the presence of the uncoupling agent carbenoxolone (Ishimatsu and Williams, 1996). Altogether, these results show that $\alpha 9$-containing nAChRs are involved in the tonic inhibitory control exerted by cholinergic signaling on gap junction-mediated cell-cell communication in the adrenal medulla, as previously reported for $\alpha 3$ - and $\alpha 7$-built nAChRs (Martin et al., 2003).

Altogether, our findings showing the contribution of $\alpha 9$ containing $\mathrm{nAChRs}$ to synaptic transmission and to regulation of gap junctional communication strengthen the hypothesis that these nAChRs may be functionally relevant for stimulus-secretion coupling in the adrenal medulla.

\section{Upregulation of $\alpha 9 \mathrm{nAChR}$ channel protein expression level in cold-stressed rats}

Our finding showing the involvement of $\alpha 9$-containing nAChRs in synaptic transmission between splanchnic nerve endings and chromaffin cells prompted us to investigate the expression level of these receptors in a condition associated with an increased synaptic transmission. In addition to its well described effects on expression of genes and proteins involved in the catecholamine biosynthesis (Baruchin et al., 1990; Kvetnanský and Sabban, 1993; Sabban and Kvetnanský, 2001), cold stress also triggers long-lasting anatomical and functional remodeling of intercellular communication in the rat adrenal medulla. In particular, synaptic activity is upregulated (Colomer et al., 2008a). Do $\alpha 9$-containing nAChRs play a role in cold stress-induced increased synaptic activity? Because nAChR function can be regulated at the transcriptional, translational, and posttranslational level (Laufer and Changeux, 1989; Fornasari et al., 1998; Albuquerque et al., 2009), we examined the expression level of both $\alpha 9$ $\mathrm{nAChR}$ protein and transcript in cold-exposed rats.

The membrane content of $\alpha 9$ nAChRs was measured by Western blot. As illustrated in Figure 6A, $\alpha 9$ nAChRs protein level was 
A

\section{control}
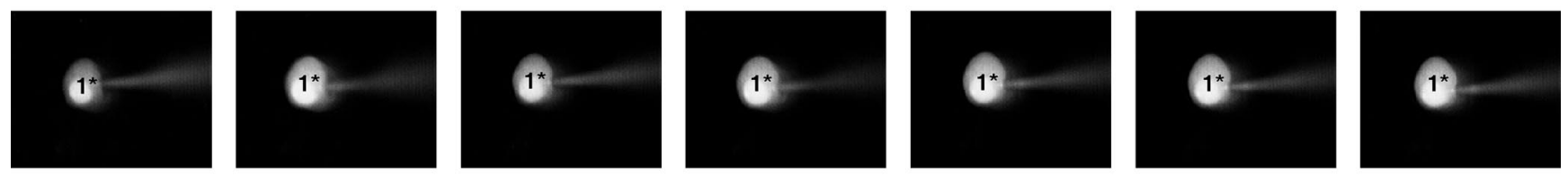

$\alpha$-RglA
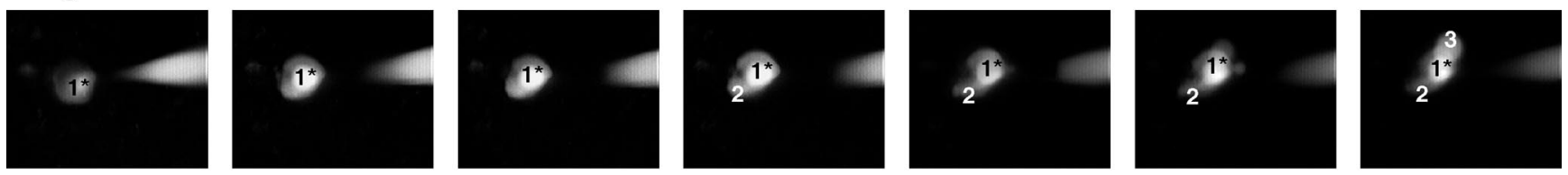

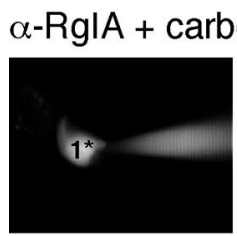

0

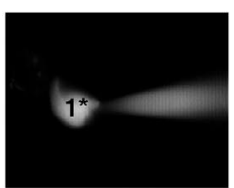

5

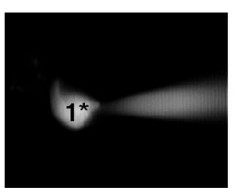

10

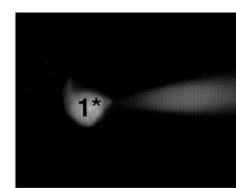

15

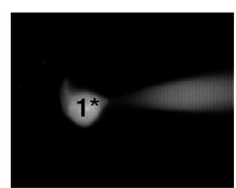

20

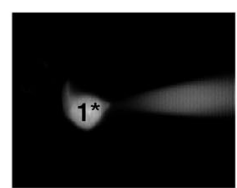

25

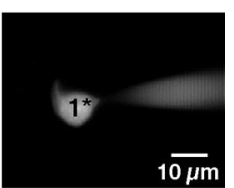

$30 \mathrm{~min}$
B

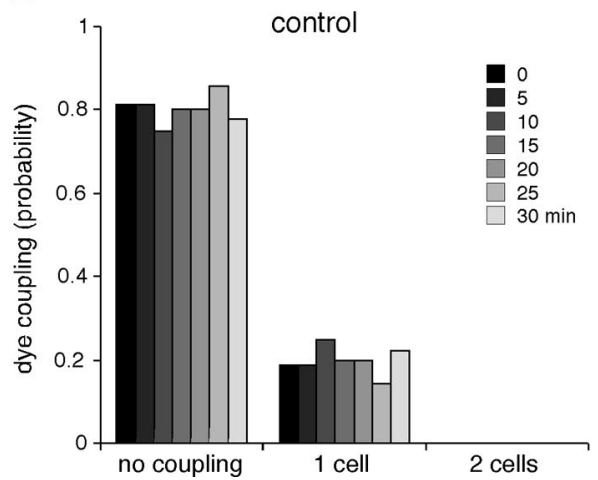

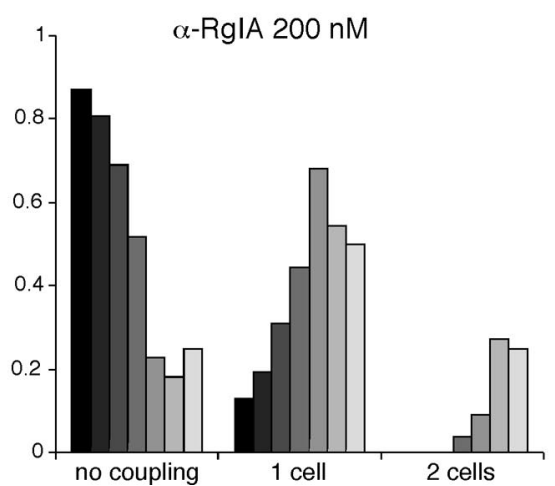

$\alpha-R g I A 200 \mathrm{nM}+$

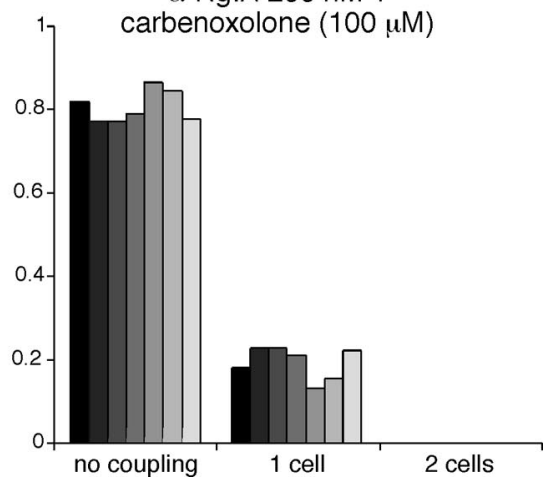

Figure 5. Increased LY diffusion after $\alpha 9$-containing $n A C h R$ blockade. $A$, Time-lapse recordings (one frame per 5 min for $30 \mathrm{~min}$ ) of LY diffusion in adrenal slices under different experimental conditions. $1^{*}$ represents the LY-injected cell. Whereas the number of LY-labeled cells does not change in the control slice (top row), it gradually increases after 15-20 min in the $\alpha$-RglA-exposed slice (middle row). The increased LY diffusion occurs through a gap junctional pathway, as evidenced by its blockade in the $\alpha$-RglA + carbenoxolone-treated slice (bottom row). $\boldsymbol{B}$, Pooled data. Each histogram bar represents the pooled data obtained from 4 to 31 cells.

upregulated in stressed rats. The level of $\alpha 9 \mathrm{nAChR}$ expression being normalized to that of actin, the quantitative analysis showed a significant upregulation (1.8-fold increase) of $\alpha 9$-built $n A C h R s$ in cold-stressed rats compared with unstressed animals (mean ratio $\alpha 9 \mathrm{nAChR} /$ actin of $0.45 \pm 0.04, n=6$ for control rats vs $0.82 \pm 0.05, n=6$ for cold-exposed rats, $p<0.05$ ).

As a first step toward the characterization of the mechanisms involved in increased $\alpha 9 \mathrm{nAChR}$ expression in cold-exposed rats, we examined by real-time PCR whether the expression level of its transcript was modified. Total RNA was extracted from macrodissected adrenal medulla from 13 control and 12 cold-exposed rats. Expression of nAChR subtype mRNA was normalized to the geometric mean of the expression levels of Hprt, GAPDH, and Gus mRNA. $\alpha 9$ $\mathrm{nAChR}$ mRNA relative expression level was 5.2-fold higher in stressed rats $(23.6 \pm 7.9$ vs $4.5 \pm 1.2$ in stressed and control rats, respectively; $p<0.05$ ) (Fig. $6 B$ ). Interestingly, no change was observed for $\alpha 3$ - and $\alpha 7$-built nAChR transcripts (relative expression $249 \pm 48$ vs $186 \pm 51$ for stressed and control rats, respectively; $p>$ 0.05 for $\alpha 3 \mathrm{nAChRs}$ and $159 \pm 18$ vs $118 \pm 16$ for stressed and control rats, respectively; $p>0.05$ for $\alpha 7 \mathrm{nAChRs)}$ (Fig. 6B).
Major contribution of $\alpha 9$-containing $\mathrm{nAChRs}$ in mediating acetylcholine-evoked inward currents in cold-stressed rats What could be the functional consequence of the upregulation of $\alpha 9 \mathrm{nAChR}$ subunit in cold-stressed rats? We addressed this issue by investigating the effects of $\alpha$-RgIA on acetylcholine-evoked inward current in acute slices from unstressed and cold-stressed rats (Fig. 7). Chromaffin cells were voltage-clamped at $-40 \mathrm{mV}$ and briefly stimulated by pressure-applied ACh (100 $\mu \mathrm{M}, 1 \mathrm{~s})$. The recorded cell was then bathed for $4 \mathrm{~min}$ in saline, $\alpha$-RgIA, hexamethonium, or a mixed solution containing $\alpha$-RgIA and hexamethonium. The cell was then restimulated with ACh. Density of ACh-triggered inward currents was compared between the different perfusing conditions. The reversibility of the observed effect was examined 5 min later upon a third ACh application. In the absence of a nicotinic receptor blocker, ACh-induced currents did not rundown, either in unstressed (Fig. 7Aa, left panel) or in cold-stressed (Fig. 7Aa, right panel) rats. In addition, the current density did not significantly differ between control and stressed animals $(30.0 \pm 1.6 \mathrm{pA} / \mathrm{pF}, n=52$ vs $33.4 \pm 1.0 \mathrm{pA} / \mathrm{pF}$, $n=57$ for control and stressed rats, respectively; $p>0.05$ ) (data 


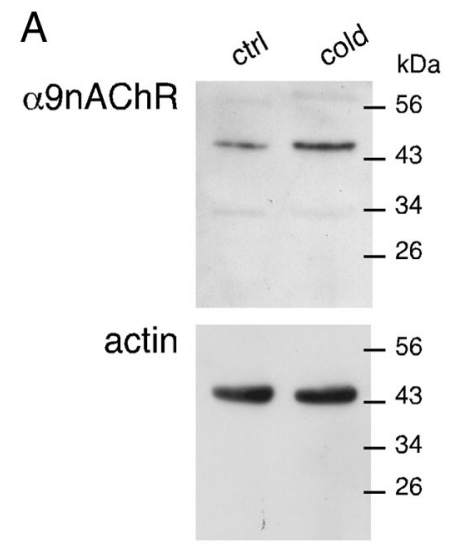

B

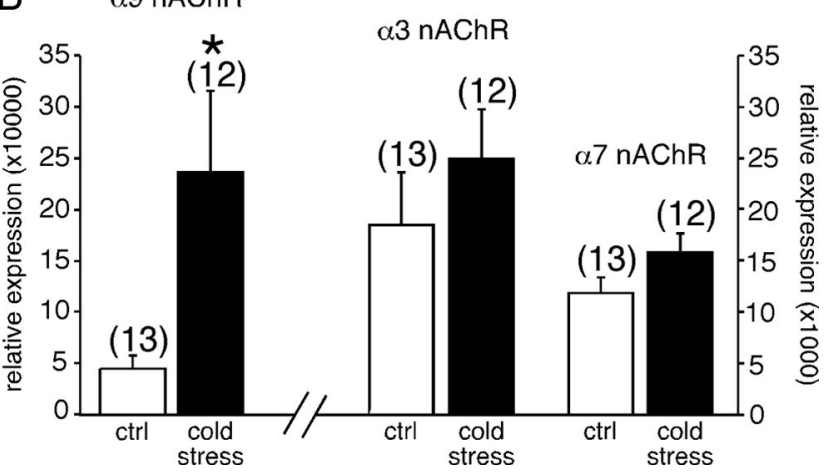

Figure 6. Upregulation of $\alpha 9 \mathrm{nAChR}$ protein and transcript expression levels in cold-stressed rats. $A$, Representative immunoblots showing specific detection of $\alpha 9 \mathrm{nAChR}$ in the adrenal medulla of control and cold-stressed rats (top panel). Actin was used as an internal loading control. Histogram summarizing the densitometric analysis of immunoblots (normalized by actin) from six control and six stressed rats (bottom panel). Quantitative analysis shows that $\alpha 9 \mathrm{nAChR}$ expression level was significantly increased (1.8-fold) in stressed rats. ${ }^{*} p<0.05$ compared with unstressed rats. $\boldsymbol{B}$, Expression levels of $\alpha 9-, \alpha 3-$, and $\alpha 7 \mathrm{nAChR}$ subunits were determined by quantitative PCR. Total RNA was extracted from macrodissected adrenal medulla from 13 control and 12 cold-stressed rats. Expression of nAChR mRNA was normalized to the geometric mean of the expression levels of $\mathrm{Hprt}, \mathrm{GAPDH}$, and Gus mRNA. A significant increase in relative expression level was observed for $\alpha 9 \mathrm{nAChR}$ but not for $\alpha 3 \mathrm{nAChR}$ and $\alpha 7 \mathrm{nAChR}$ transcripts. ${ }^{*} p<0.05$, compared with unstressed rats.

not shown). As expected for nicotinic receptor blockers, both $\alpha$-RgIA (200 nM) and hexamethonium (200 $\mu \mathrm{M})$ reduced AChinduced inward current (Figs. $7 A$ for raw data and Fig. $7 B$ for pooled data). However, their blocking effect significantly differed between control and stressed rats, pointing to a differential contribution of $\alpha 9$-containing $\mathrm{nAChRs}$ and other $\mathrm{nAChRs}$ to AChmediated currents. $\alpha$-RgIA (200 nM) reduced ACh currents in stressed rats by $75.5 \%(n=26)$, whereas it reduced them by only $39.3 \%(n=22)$ in unstressed rats $(p<0.05)$ (Fig. $7 C)$. Conversely, hexamethonium $(200 \mu \mathrm{M})$ mainly reduced ACh-evoked currents in control rats $(76.2 \%$ reduction, $n=11)$ but decreased them by only $44.6 \%(n=13, p<0.05)$ (Fig. $7 C)$ in cold-stressed rats. When applied together, $\alpha$-RgIA and hexamethonium had comparable effects on cholinergic currents $(90.8 \%, n=6$ vs $90.5 \%, n=12$, in unstressed and stressed rats, respectively; $p>$ 0.05) (Fig. 7C). Note that the blocking effect was not complete, indicating that other $\mathrm{nAChRs}$ are likely involved in the current generation. Altogether, these results show a major contribution of $\alpha 9$-containing nAChR channels in ACh-evoked current in cold-stressed rats.

To go further, we next compared the kinetics of $\alpha$-RgIA- and hexamethonium-induced blocking effect in both control and cold-stressed rats. ACh-evoked current density was calculated 1,
4, and $5 \mathrm{~min}$ after nicotinic receptor antagonist application (Fig. 8 ). In control rats, the blocking effect of $\alpha$-RgIA was complete after 1 min; however, it took 4 min in cold-stressed rats. Regarding hexamethonium, its blocking effect on ACh-evoked current was complete within 4 min in control animals and was still under process after $5 \mathrm{~min}$ in stressed rats. Assuming that receptor antagonists sequentially reach their extrasynaptic and synaptic targets, blocking kinetics may be used as indicator of synaptic and extrasynaptic nAChRs localization. Our results are in favor of a preferential synaptic localization of $\alpha 9$-containing $\mathrm{nAChRs}$ vs $\alpha 3$-built nAChRs in cold-stressed rats. Conversely, in control rats, $\alpha 9$ containing nAChRs would be preferentially extrasynaptic and $\alpha 3$ nAChRs would be the dominant nAChR channels expressed at the splanchnic nerve-chromaffin cell synapse. To test the hypothesis that $\alpha 9$-containing nAChRs preferentially localize close to the synaptic sites in stressed rats, a dual immunodetection of synaptophysin and $\alpha 9$-containing $\mathrm{nAChRs}$ was performed in stressed and unstressed rats. The percentage of codistribution of synaptophysin over $\alpha 9$-containing nAChRs was assessed quantitatively by using confocal microscopy, as previously described (Chauvet et al., 2003). As illustrated in Figure 9, the codistribution of synaptophysin with $\alpha 9$-containing nAChRs was significantly higher in cold-stressed rats, compared with controls $(40.5 \pm 4.1 \%, n=12$ vs $23.9 \pm 3.9, n=12$, respectively; $p<$ $0.05)$. Altogether, these results suggest a recruitment of $\alpha 9$ containing $\mathrm{nAChRs}$ at synaptic sites in cold-stressed rats.

\section{Discussion}

This study documents for the first time functional roles of $\alpha 9$ containing $\mathrm{nAChR}$ channels in the rat adrenal medulla. We report that (1) these receptors are activated upon synaptic transmission between splanchnic nerve endings and chromaffin cells and (2) they tonically inhibit gap junctional coupling between chromaffin cells. Additionally, our findings provide evidences that $\alpha 9 \mathrm{nAChR}$ subunit is upregulated in cold-stressed rats, consistent with a dominant contribution of $\alpha 9$-containing nAChRs to ACh-evoked currents.

\section{Activation of $\alpha 9$-containing nAChRs in response to synaptic release of $\mathrm{ACh}$}

Both electrophysiological data showing reduced sEPSC amplitude and frequency in the presence of $\alpha$-RgIA and the distribution of $\alpha 9 \mathrm{nAChRs}$ close to the synaptic marker synaptophysin suggest that $\alpha 9 \mathrm{nAChR}$ channels contribute to cholinergic synaptic transmission. Since $\alpha 10$ subunit confers functionality to $\alpha 9$ nAChRs (Sgard et al., 2002; Vetter et al., 2007), it is likely that the functional nAChRs are composed of both $\alpha 9$ and $\alpha 10$ subunits. Taking into consideration (1) the apparent affinity of $\alpha 9$ and $\alpha 9 / \alpha 10$ nAChRs for ACh [( $\mathrm{EC}_{50}$ of $\sim 27 \mu \mathrm{M}$ and $\sim 30 \mu \mathrm{M}$, respectively (Sgard et al., 2002)] and (2) the concentration of ACh in the synaptic cleft [up to $1 \mathrm{~mm}$ during quantal response (MatthewsBellinger and Salpeter, 1978)], activation of $\alpha 9$-containing nAChRs in response to synaptically released ACh is highly plausible. In this context, our report extends previous contributions showing the involvement of $\alpha 9$-containing nAChRs receptors in neuronal synaptic transmission. Indeed, they mediate cholinergic synaptic transmission between olivocochlear fibers and cochlear outer hair cells (Elgoyhen et al., 1994, 2001; Vetter et al., 2007) and are involved in synaptogenesis (Vetter et al., 1999).

Regarding cholinergic neurotransmission at rat splanchnic nerve-chromaffin cell synapses, we provide evidence that, in addition to $\alpha 3$ and $\alpha 7 \mathrm{nAChRs}$ (Barbara and Takeda, 1996; Martin et al., 2003), nAChRs built by assembly of $\alpha 9$ and/or $\alpha 9 / \alpha 10$ subunits are activated during synaptic release of ACh. Addition- 
A

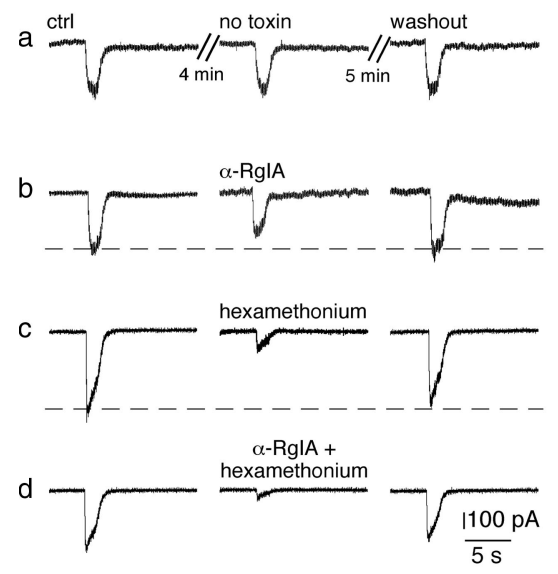

cold stress
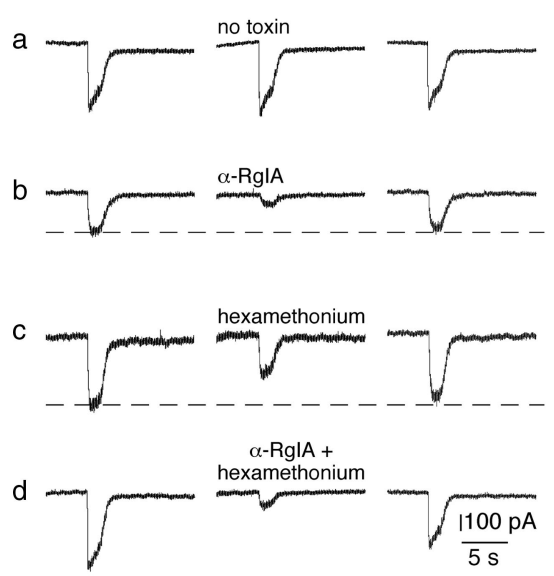

B

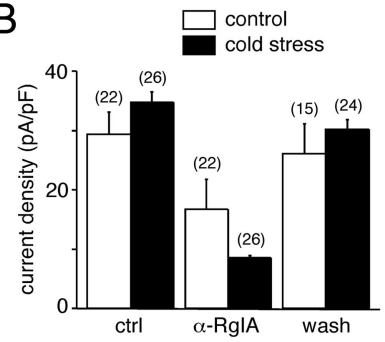

C

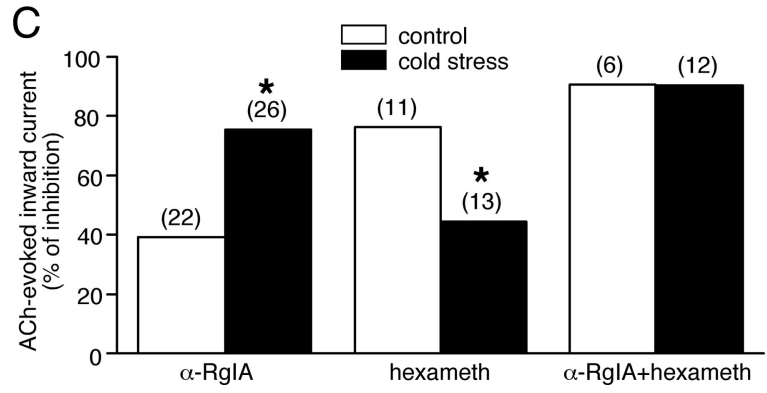

Figure 7. Dominant contribution of $\alpha 9$-containing $n A C h R s$ in acetylcholine-evoked current in cold-stressed rats. $\boldsymbol{A}$, Individual chromaffin cells from control and cold-stressed rats were voltage-clamped at $-40 \mathrm{mV}$ and stimulated by a $1 \mathrm{~s}$ application of $A C h$ (100 $\mu \mathrm{m})$. $\boldsymbol{A}$, Representative ACh-triggered current recorded in the absence of toxin and $4 \mathrm{~min}$ after $\alpha$-RgIA (200 nm), hexamethonium (200 $\mu \mathrm{M})$, or $\alpha$-RgIA + hexamethonium applications. Note that the stronger blockade of ACh-evoked current is observed for hexamethonium in control rats and for $\alpha$-RglA in cold-stressed rats. $\boldsymbol{B}$, Histograms illustrating the blockade efficiency of $\alpha$-RgIA, hexamethonium, and $\alpha$-RglA + hexamethonium on ACh current density in control and cold-stressed rats. Note that in each condition, toxins' effects are fully reversible. $C$, Histogram illustrating the percentage of inhibition of the ACh-evoked inward current by $\alpha$-RgIA, hexamethonium, and $\alpha$-RgIA + hexamethonium in control and cold-stressed rats.

ally, our data describing an $\alpha$-RgIA-induced decrease of both sEPSC frequency and amplitude fit with the presence of synapses containing pure $\alpha 9$-containing nAChRs and synapses containing a mixture of $\alpha 9$-containing and other nAChRs (such as $\alpha 3$ and/or $\alpha 7)$. The respective contribution of $\alpha 9$ and/or $\alpha 9 / \alpha 10, \alpha 3$, and $\alpha 7 \mathrm{nAChR}$ channels to sEPSCs still remains to be quantified. Based on the blocking effects of $\alpha$-RgIA and hexamethonium, $\alpha 3 \mathrm{nAChRs}$ appear to preferentially mediate sEPSCs in control rats, as previously reported (Barbara and Takeda, 1996), whereas $\alpha 9$-containing $n A C h R s$ predominantly mediate sEPSCs in cold-stressed rats. The contribution of $\alpha 7 \mathrm{nAChRs}$ needs further investigation, keeping in mind that $\alpha 7$ and $\alpha 10$ subunits can be spatially associated (Lips et al., 2006). The involvement of $\alpha 7 \mathrm{nAChRs}$ in adrenal synaptic transmission has been evidenced by the blocking effect of $\alpha$-bungarotoxin ( $\alpha$-Bgt) on sEPSCs (Martin et al., 2003). However, $\alpha$-Bgt antagonizes not only $\alpha 7$ nAChRs ( IC $_{50} 1.6 \mathrm{nM}$ ) (López et al., 1998), but also $\alpha 9$ and $\alpha 9 / \alpha 10$ nAChRs $\left(\mathrm{IC}_{50} 2.1\right.$ and 14 $\mathrm{nM}$, respectively) (Sgard et al., 2002). Although other data support the presence of $\alpha 7$ nAChRs in adrenal chromaffin cells (Rust et al., 1994; Criado et al., 1997; Mousavi et al., 2001), their contribution to synaptic transmission merits reexamination by using, for example, the highly selective $\alpha 7$ nAChRantagonist $\alpha$-conotoxin ArIB[V11L, V16D] (Whiteaker et al., 2007).

\section{Functional relevance of $\alpha 9$-containing nAChRs in the stimulus-secretion coupling}

Because $\alpha 9$ nAChRs are highly permeable to $\mathrm{Ca}^{2+}$ (Jagger et al., 2000; Katz et al., 2000; Fucile et al., 2006) and an increase in cytosolic $\mathrm{Ca}^{2+}\left(\left[\mathrm{Ca}^{2+}\right] i\right)$ is a prerequisite for chromaffin cell exocytosis (Cheek, 1991), it is likely that $\alpha 9$ nAChR activation by ACh would trigger instructive signaling cascades contributing to catecholamine release from chromaffin cells.

Consistent with their high $\mathrm{Ca}^{2+}$ permeability (Jagger et al., 2000), $\alpha 9$ containing $\mathrm{nAChRs}$ have been reported to interact with the small-conductance $\mathrm{Ca}^{2+}$-dependent $\mathrm{K}^{+}$(SK) channels (Nie et al., 2004). Therefore, SK channelmediated currents can be gated by $\alpha 9$ nAChRs (Kong et al., 2006) and SK channels are required for expression of functional $\alpha 9 / \alpha 10$ nAChRs (Kong et al., 2008). Because activation of SK channels by ACh negatively regulates cell excitability (Nenov et al., 1996; Nakajima et al., 2007), it is tempting to speculate that SK channels shorten the depolarizing action of synaptically released ACh, thereby preventing the formation of a depolarizing plateau in case of high-frequency synaptic activity at the splanchnic nerve-chromaffin cell junction. On the other hand, one could propose that $\alpha 9$-containing nAChRs modulate SK channel trafficking and remove them from synapses, as described for $\beta$-adrenoceptors (Faber et al., 2008). Thus, cholinergic neurotransmission at the splanchnic synapses would initially be more robust. The discrimination between these two hypotheses needs further study.

The increased LY diffusion between chromaffin cells in the presence of $\alpha$-RgIA indicates that activation of $\alpha 9$-containing nAChRs negatively modulates gap junctional coupling, thus extending data showing that cholinergic synaptic inputs play a tonic inhibitory control on gap junction-mediated communication (Martin et al., 2003). Because coordination of cellular and intercellular responses is crucial in maintaining tissular syncytial function (Ramanan et al., 1998), we hypothesize that negative modulation of gap junctional coupling by synaptic transmission in basal condition acts as a shield to protect the organism against a huge catecholamine release potentially harmful or even lethal. Conversely, upon a reduced synaptic transmission, it may act as a 

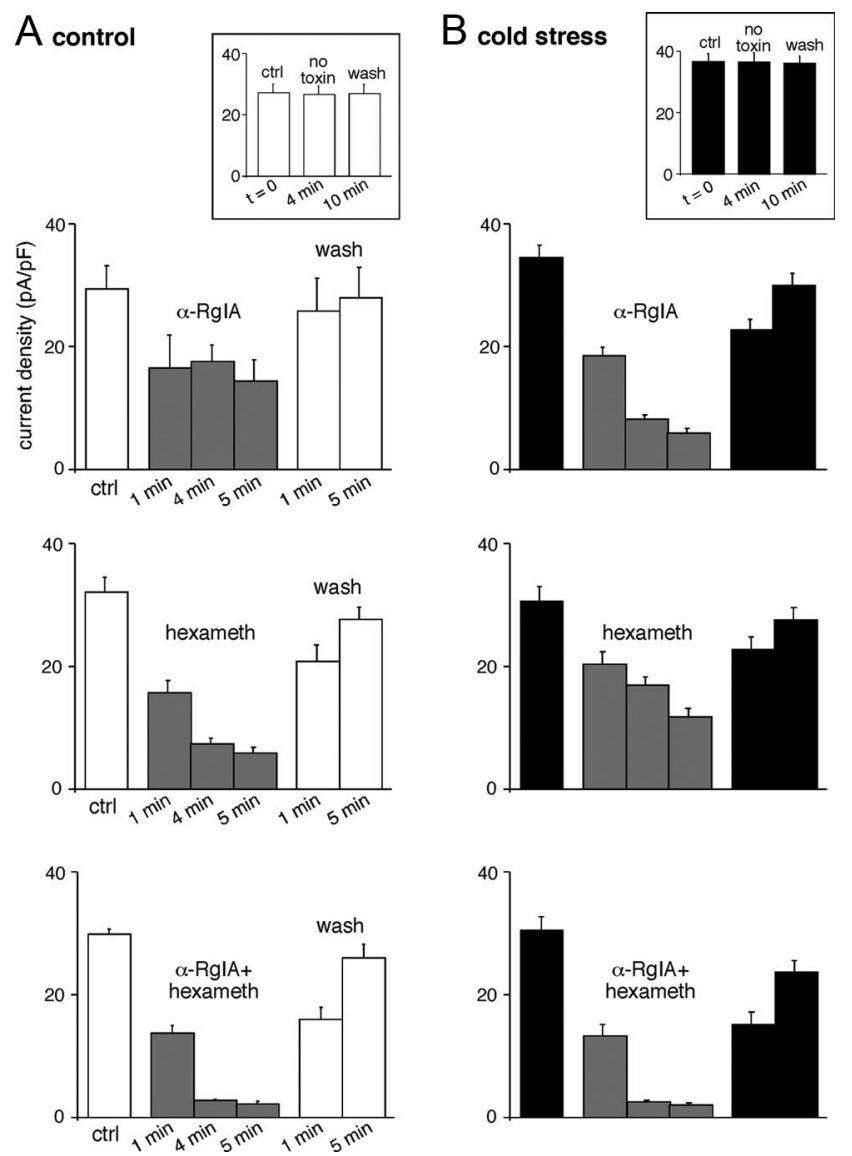

Figure 8. Time course of the blocking effect of $\alpha$-RgIA and hexamethonium (hexameth) on acetylcholine-evoked current in control and cold-stressed rats. $A, B, A C h$ current density was calculated before and 1, 4, and 5 min after blocker application and after 1 and 5 min washout (wash) in control $(\boldsymbol{A})$ and cold-stressed $(\boldsymbol{B})$ rats. ACh-evoked current did not rundown over the 10 min recording (insets). In control rats, the blocking effect of $\alpha$-RglA was complete after 1 min, whereas it required at least $4 \mathrm{~min}$ in cold-stressed rats. Regarding hexamethonium, the blocking effect was complete within 4 min in control animals and was still under process after 5 min in stressed rats.

compensation lever to sustain catecholamine release by maintaining communication within the chromaffin cell network.

Dominant expression and function of $\alpha 9$-containing nAChRs in cold-stressed rats: an added value?

The major contribution of $\alpha 9$-containing nAChRs to AChevoked currents in stressed rats parallels an upregulation of $\alpha 9$ nAChR transcript expression level, consistent with the fact that the $\alpha 9$ nAChR gene undergoes transcriptional regulation (Valor et al., 2003). The associated upregulation of $\alpha 9 \mathrm{nAChR}$ protein expression level is also in agreement with posttranslational regulation and a possible mechanism would involve receptor trafficking, as observed for other nAChR subtypes (Gaimarri et al., 2007).

With regard to changes in adrenal $\mathrm{nAChR}$ expression levels in stressed rats, data are sparse and only a recent study reports a decrease in $\alpha 7 \mathrm{nAChR}$ messenger in response to long-term hypoxia (Ducsay et al., 2007). By contrast, as reported here in coldstressed rats, the expression level of transcripts encoding $\alpha 3$ and $\alpha 7 \mathrm{nAChR}$ subunits remained unchanged, indicating that the regulation of $n A C h R$ expression is stressor specific. This specific regulation of $\mathrm{nAChRs}$ exhibiting different intrinsic properties
A

control

B
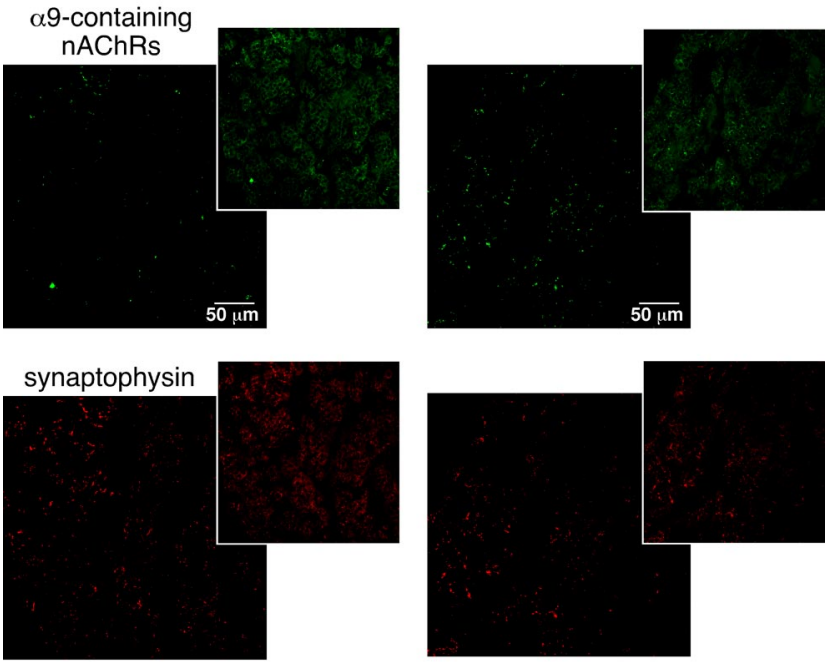

merge
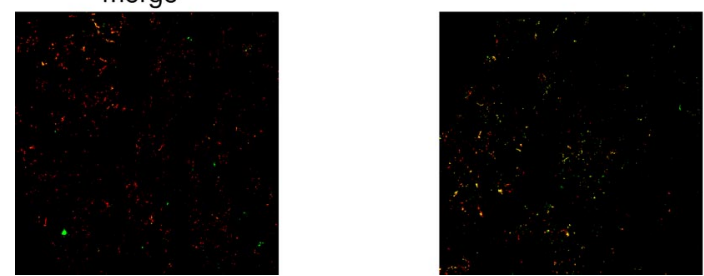

Figure 9. Preferential codistribution of $\alpha 9$-containing $\mathrm{nAChRs}$ with synaptophysin in coldstressed rats. $\boldsymbol{A}, \boldsymbol{B}$, Synaptophysin and $\alpha$-containing nAChRs were detected in control $(\boldsymbol{A})$ and cold-exposed $(\boldsymbol{B})$ rats by immunofluorescence. The pictures (pseudocolored in green and red for $\alpha 9 \mathrm{nAChRs}$ and synaptophysin, respectively) represent the thresholded images to which a binary transformation was applied (see Material and Methods). Original pictures for each staining are shown in insets.

(gating, $\mathrm{Ca}^{2+}$ permeability, etc.) may allow chromaffin cells to appropriately respond to a variety of environmental changes.

The preponderant blockade of ACh-induced current by $\alpha$-RgIA $(>70 \%)$ and the preferential localization of $\alpha 9$-containing $\mathrm{nAChRs}$ at synaptic sites observed in cold-exposed rats led us to propose that $\alpha 9$-containing nAChRs play a dominant role in the postsynaptic detection of cholinergic inputs in stressed animals. By contrast, in unstressed rats, $\alpha 9$-containing nAChRs contribute to a lesser extent to ACh-evoked current, the major contribution being that of $\alpha 3 \mathrm{nAChRs}$, consistent with a dominant expression of $\alpha 3 / \beta 4 \mathrm{nAChRs}$ in chromaffin cells (Criado et al., 1992; Campos-Caro et al., 1997; Sala et al., 2008). We propose that under resting conditions, in which expression level of $\alpha 9$ subunit is low, the synaptic response of chromaffin cells would be dominated by $\alpha 3$ subunit-containing nAChRs (Barbara and Takeda, 1996; Martin et al., 2003, 2005) that exhibit low $\mathrm{Ca}^{2+}$ permeability (Fucile, 2004). Interestingly, transmural electrical stimulation of bisected adrenals intermittently failed to evoke action potentials when the stimulus frequency was $>10 \mathrm{~Hz}$ (Holman et al., 1994). Moreover, the few action potentials fired in this condition arose from a depolarized membrane potential and appeared somewhat inactivated, thus suggesting a depolarization block. These observations are consistent with that of Iijima and colleagues (1992), who reported that action potentials in rat chromaffin cells began to fail when the stimulus frequency was $>20$ Hz. This suggests that chromaffin cells are not adequately prepared to increase their electrical and their secretory responses 
when the firing rate of preganglionic neurons increases above 10 $\mathrm{Hz}$, although such frequencies are commonly observed in animals under prolonged asphyxia or even in resting conditions (Iggo and Vogt, 1960; Beacham and Perl, 1964). The upregulation of $\alpha 9 \mathrm{nAChR}$ expression level reported here in cold-exposed rats, associated with the fact that these receptors exhibit a higher $\mathrm{Ca}^{2+}$ permeability than other nAChRs, would provide a mechanism by which enhanced synaptic $\mathrm{Ca}^{2+}$ entry through this receptor subtype and the ensuing activation of SK channels would shape excitatory synaptic potentials in a way that would enable chromaffin cells to repetitively and faithfully discharge action potentials to cope with stressful situations as manifested by a high frequency of splanchnic nerve firing.

\section{References}

Albuquerque EX, Pereira EF, Alkondon M, Rogers SW (2009) Mammalian nicotinic acetylcholine receptors: from structure to function. Physiol Rev 89:73-120.

Barbara JG, Takeda K (1996) Quantal release at a neuronal nicotinic synapse from rat adrenal gland. Proc Natl Acad Sci U S A 93:9905-9909.

Baruchin A, Weisberg EP, Miner LL, Ennis D, Nisenbaum LK, Naylor E, Stricker EM, Zigmond MJ, Kaplan BB (1990) Effects of cold exposure on rat adrenal tyrosine hydroxylase: an analysis of RNA, protein, enzyme activity, and cofactor levels. J Neurochem 54:1769-1775.

Beacham WS, Perl ER (1964) Background and reflex discharge of sympathetic preganglionic neurones in the spinal cat. J Physiol 172:400-416.

Campos-Caro A, Smillie FI, Domínguez del Toro E, Rovira JC, VicenteAgulló F, Chapuli J, Juíz JM, Sala S, Sala F, Ballesta JJ, Criado M (1997) Neuronal nicotinic acetylcholine receptors on bovine chromaffin cells: cloning, expression, and genomic organization of receptor subunits. J Neurochem 68:488-497.

Cartier GE, Yoshikami D, Gray WR, Luo S, Olivera BM, McIntosh JM (1996) A new alpha-conotoxin which targets alpha3beta2 nicotinic acetylcholine receptors. J Biol Chem 271:7522-7528.

Chauvet N, Prieto M, Fabre C, Noren NK, Privat A (2003) Distribution of p120 catenin during rat brain development: potential role in regulation of cadherin-mediated adhesion and actin cytoskeleton organization. Mol Cell Neurosci 22:467-486.

Cheek TR (1991) Calcium signalling and the triggering of secretion in adrenal chromaffin cells. Pharmacol Ther 52:173-189.

Colomer C, Lafont C, Guérineau NC (2008a) Stress-induced intercellular communication remodeling in the rat adrenal medulla. Ann N Y Acad Sci 1148:106-111.

Colomer C, Olivos-Oré LA, Coutry N, Mathieu MN, Arthaud S, Fontanaud P, Iankova I, Macari F, Thouënnon E, Yon L, Anouar Y, Guérineau NC (2008b) Functional remodeling of gap junction-mediated electrical communication between adrenal chromaffin cells in stressed rats. J Neurosci 28:6616-6626.

Colomer C, Desarménien MG, Guérineau NC (2009) Revisiting the stimulus-secretion coupling in the adrenal medulla: role of gap junctionmediated intercellular communication. Mol Neurobiol 40:87-100.

Criado M, Alamo L, Navarro A (1992) Primary structure of an agonist binding subunit of the nicotinic acetylcholine receptor from bovine adrenal chromaffin cells. Neurochem Res 17:281-287.

Criado M, Domínguez del Toro E, Carrasco-Serrano C, Smillie FI, Juíz JM, Viniegra S, Ballesta JJ (1997) Differential expression of $\alpha$-bungarotoxin-sensitive neuronal nicotinic receptors in adrenergic chromaffin cells: a role for transcription factor Egr-1. J Neurosci 17:6554-6564.

Di Angelantonio S, Matteoni C, Fabbretti E, Nistri A (2003) Molecular biology and electrophysiology of neuronal nicotinic receptors of rat chromaffin cells. Eur J Neurosci 17:2313-2322.

Douglas WW (1968) Stimulus-secretion coupling: the concept and clues from chromaffin and other cells. Br J Pharmacol 34:451-474.

Douglas WW, Rubin RP (1961) Mechanism of nicotinic action at the adrenal medulla: calcium as a link in stimulus-secretion coupling. Nature 192:1087-1089.

Ducsay CA, Hyatt K, Mlynarczyk M, Root BK, Kaushal KM, Myers DA (2007) Long-term hypoxia modulates expression of key genes regulating adrenomedullary function in the late gestation ovine fetus. Am J Physiol Regul Integr Comp Physiol 293:R1997-R2005.
Elgoyhen AB, Johnson DS, Boulter J, Vetter DE, Heinemann S (1994) Alpha9: an acetylcholine receptor with novel pharmacological properties expressed in rat cochlear hair cells. Cell 79:705-715.

Elgoyhen AB, Vetter DE, Katz E, Rothlin CV, Heinemann SF, Boulter J (2001) Alpha10: a determinant of nicotinic cholinergic receptor function in mammalian vestibular and cochlear mechanosensory hair cells. Proc Natl Acad Sci U S A 98:3501-3506.

Ellison M, Haberlandt C, Gomez-Casati ME, Watkins M, Elgoyhen AB, McIntosh JM, Olivera BM (2006) Alpha-RgIA: a novel conotoxin that specifically and potently blocks the alpha9alpha10 nAChR. Biochemistry 45:1511-1517.

Ellison M, Feng ZP, Park AJ, Zhang X, Olivera BM, McIntosh JM, Norton RS (2008) Alpha-RgIA, a novel conotoxin that blocks the alpha9alpha10 nAChR: structure and identification of key receptor-binding residues. J Mol Biol 377:1216-1227.

Faber ES, Delaney AJ, Power JM, Sedlak PL, Crane JW, Sah P (2008) Modulation of SK channel trafficking by beta adrenoceptors enhances excitatory synaptic transmission and plasticity in the amygdala. J Neurosci 28:10803-10813.

Fornasari D, Battaglioli E, Terzano S, Clementi F (1998) Transcriptional regulation of neuronal nicotinic receptors subunit genes. In: Neuronal nicotinic receptors: pharmacology and therapeutic opportunities (Arneric SP, Brioni JD, eds), pp 25-42. New York: Wiley.

Fucile S (2004) $\mathrm{Ca}^{2+}$ permeability of nicotinic acetylcholine receptors. Cell Calcium 35:1-8.

Fucile S, Sucapane A, Eusebi F (2006) $\mathrm{Ca}^{2+}$ permeability through rat cloned alpha9-containing nicotinic acetylcholine receptors. Cell Calcium 39: 349-355.

Gaimarri A, Moretti M, Riganti L, Zanardi A, Clementi F, Gotti C (2007) Regulation of neuronal nicotinic receptor traffic and expression. Brain Res Rev 55:134-143.

Hamill OP, Marty A, Neher E, Sakmann B, Sigworth FJ (1981) Improved patch-clamp techniques for high-resolution current recording from cells and cell-free membrane patches. Pflügers Arch 391:85-100.

Holman ME, Coleman HA, Tonta MA, Parkington HC (1994) Synaptic transmission from splanchnic nerves to the adrenal medulla of guineapigs. J Physiol 478:115-124.

Iggo A, Vogt M (1960) Preganglionic sympathetic activity in normal and in reserpine-treated cats. J Physiol 150:114-133.

Iijima T, Matsumoto G, Kidokoro Y (1992) Synaptic activation of rat adrenal medulla examined with a large photodiode array in combination with a voltage-sensitive dye. Neuroscience 51:211-219.

Ishimatsu M, Williams JT (1996) Synchronous activity in locus coeruleus results from dendritic interactions in pericoerulear regions. J Neurosci 16:5196-5204.

Jagger DJ, Griesinger CB, Rivolta MN, Holley MC, Ashmore JF (2000) Calcium signalling mediated by the 9 acetylcholine receptor in a cochlear cell line from the immortomouse. J Physiol 527:49-54.

Kajiwara R, Sand O, Kidokoro Y, Barish ME, Iijima T (1997) Functional organization of chromaffin cells and cholinergic synaptic transmission in rat adrenal medulla. Jpn J Physiol 47:449-464.

Katz E, Verbitsky M, Rothlin CV, Vetter DE, Heinemann SF, Elgoyhen AB (2000) High calcium permeability and calcium block of the alpha9 nicotinic acetylcholine receptor. Hear Res 141:117-128.

Kong JH, Adelman JP, Fuchs PA (2008) Expression of the SK2 calciumactivated potassium channel is required for cholinergic function in mouse cochlear hair cells. J Physiol 586:5471-5485.

Kong WJ, Guo CK, Zhang S, Zhang XW, Wang YJ, Li ZW (2006) Fast cholinergic efferent inhibition in guinea pig outer hair cells. Brain Res 1102:103-108.

Kvetnanský R, Sabban EL (1993) Stress-induced changes in tyrosine hydroxylase and other catecholamine biosynthetic enzymes. In: Tyrosine hydroxylase: from discovery to cloning (Naoi M, Parvez SH, eds), pp 253-281. Utrecht, The Netherlands: VSP.

Laufer R, Changeux JP (1989) Activity-dependent regulation of gene expression in muscle and neuronal cells. Mol Neurobiol 3:1-53.

Lips KS, König P, Schätzle K, Pfeil U, Krasteva G, Spies M, Haberberger RV, Grando SA, Kummer W (2006) Coexpression and spatial association of nicotinic acetylcholine receptor subunits alpha7 and alpha10 in rat sympathetic neurons. J Mol Neurosci 30:15-16.

López MG, Montiel C, Herrero CJ, García-Palomero E, Mayorgas I, Hernández-Guijo JM, Villarroya M, Olivares R, Gandía L, McIntosh JM, 
Olivera BM, García AG (1998) Unmasking the functions of the chromaffin cell alpha7 nicotinic receptor by using short pulses of acetylcholine and selective blockers. Proc Natl Acad Sci U S A 95:14184-14189.

Martin AO, Mathieu MN, Chevillard C, Guérineau NC (2001) Gap junctions mediate electrical signaling and ensuing cytosolic $\mathrm{Ca}^{2+}$ increases between chromaffin cells in adrenal slices: a role in catecholamine release. J Neurosci 21:5397-5405.

Martin AO, Mathieu MN, Guérineau NC (2003) Evidence for long-lasting cholinergic control of gap junctional communication between adrenal chromaffin cells. J Neurosci 23:3669-3678.

Martin AO, Alonso G, Guérineau NC (2005) Agrin mediates a rapid switch from electrical coupling to chemical neurotransmission during synaptogenesis. J Cell Biol 169:503-514.

Matthews-Bellinger J, Salpeter MM (1978) Distribution of acetylcholine receptors at frog neuromuscular junctions with a discussion of some physiological implications. J Physiol 279:197-213.

Mousavi M, Hellström-Lindahl E, Guan ZZ, Bednar I, Nordberg A (2001) Expression of nicotinic acetylcholine receptors in human and rat adrenal medulla. Life Sci 70:577-590.

Nakajima H, Goto H, Azuma YT, Fujita A, Takeuchi T (2007) Functional interactions between the SK2 channel and the nicotinic acetylcholine receptor in enteric neurons of the guinea pig ileum. J Neurochem 103:2428-2438

Nenov AP, Norris C, Bobbin RP (1996) Acetylcholine response in guinea pig outer hair cells. II. Activation of a small conductance $\mathrm{Ca}^{2+}$-activated $\mathrm{K}^{+}$channel. Hear Res 101:149-172.

Nie L, Song H, Chen MF, Chiamvimonvat N, Beisel KW, Yamoah EN, Vázquez AE (2004) Cloning and expression of a small-conductance $\mathrm{Ca}^{2+}$-activated $\mathrm{K}^{+}$channel from the mouse cochlea: coexpression with alpha9/alpha10 acetylcholine receptors. J Neurophysiol 91:1536-1544.

Nooney JM, Feltz A (1995) Inhibition by cyclothiazide of neuronal nicotinic responses in bovine chromaffin cells. Br J Pharmacol 114:648-655.

Olivera BM, Quik M, Vincler M, McIntosh JM (2008) Subtype-selective conopeptides targeted to nicotinic receptors: Concerted discovery and biomedical applications. Channels 2:143-152.

Pérez EG, Cassels BK, Zapata-Torres G (2009) Molecular modeling of the alpha9alpha10 nicotinic acetylcholine receptor subtype. Bioorg Med Chem Lett 19:251-254.

Ramanan SV, Brink PR, Christ GJ (1998) Neuronal innervation, intracellular signal transduction and intercellular coupling: a model for syncytial tissue responses in the steady state. J Theor Biol 193:69-84.

Rust G, Burgunder JM, Lauterburg TE, Cachelin AB (1994) Expression of neuronal nicotinic acetylcholine receptor subunit genes in the rat autonomic nervous system. Eur J Neurosci 6:478-485.

Sabban EL, Kvetnanský R (2001) Stress-triggered activation of gene expres- sion in catecholaminergic systems: dynamics of transcriptional events. Trends Neurosci 24:91-98.

Sala F, Nistri A, Criado M (2008) Nicotinic acetylcholine receptors of adrenal chromaffin cells. Acta Physiol 192:203-212.

Sgard F, Charpantier E, Bertrand S, Walker N, Caput D, Graham D, Bertrand D, Besnard F (2002) A novel human nicotinic receptor subunit, alpha10, that confers functionality to the alpha9-subunit. Mol Pharmacol 61:150-159.

Valor LM, Castillo M, Ortiz JA, Criado M (2003) Transcriptional regulation by activation and repression elements located at the $5^{\prime}$-noncoding region of the human alpha9 nicotinic receptor subunit gene. J Biol Chem 278:37249-37255.

Vandesompele J, De Preter K, Pattyn F, Poppe B, Van Roy N, De Paepe A Speleman F (2002) Accurate normalization of real-time quantitative RT-PCR data by geometric averaging of multiple internal control genes. Genome Biol 3:RESEARCH0034.

Verbitsky M, Rothlin CV, Katz E, Elgoyhen AB (2000) Mixed nicotinicmuscarinic properties of the alpha9 nicotinic cholinergic receptor. Neuropharmacology 39:2515-2524.

Vetter DE, Liberman MC, Mann J, Barhanin J, Boulter J, Brown MC, SaffioteKolman J, Heinemann SF, Elgoyhen AB (1999) Role of alpha9 nicotinic ACh receptor subunits in the development and function of cochlear efferent innervation. Neuron 23:93-103.

Vetter DE, Katz E, Maison SF, Taranda J, Turcan S, Ballestero J, Liberman MC, Elgoyhen AB, Boulter J (2007) The alpha10 nicotinic acetylcholine receptor subunit is required for normal synaptic function and integrity of the olivocochlear system. Proc Natl Acad Sci U S A 104:20594-20599.

Vincler M, Wittenauer S, Parker R, Ellison M, Olivera BM, McIntosh JM (2006) Molecular mechanism for analgesia involving specific antagonism of alpha9alpha10 nicotinic acetylcholine receptors. Proc Natl Acad Sci U S A 103:17880-17884.

Wakade AR (1981) Studies on secretion of catecholamines evoked by acetylcholine or transmural stimulation of the rat adrenal gland. J Physiol 313:463-480.

Wakade AR, Wakade TD (1983) Contribution of nicotinic and muscarinic receptors in the secretion of catecholamines evoked by endogenous and exogenous acetylcholine. Neuroscience 10:973-978.

Whiteaker P, Christensen S, Yoshikami D, Dowell C, Watkins M, Gulyas J, Rivier J, Olivera BM, McIntosh JM (2007) Discovery, synthesis, and structure activity of a highly selective alpha7 nicotinic acetylcholine receptor antagonist. Biochemistry 46:6628-6638.

Wiedenmann B, Franke WW (1985) Identification and localization of synaptophysin, an integral membrane glycoprotein of $\mathrm{Mr} 38,000$ characteristic of presynaptic vesicles. Cell 41:1017-1028. 